\title{
Diagnosis and treatment of HEp-2 cells contaminated with mycoplasma
}

\author{
B. R. P. Lopes ${ }^{a, b}$ (D), A. G. Ribeiro ${ }^{a, b}$ (D), T. F. Silva ${ }^{a}$ (D), L. V. Barbosa ${ }^{a}$ (D), T. I. Jesus ${ }^{a}$ (D), \\ B. K. Matsuda ${ }^{a}$ (D), M. F. Costa ${ }^{a}$ (iD and K. A. Toledo ${ }^{a, b *}$ (D) \\ aDepartamento de Ciências Biológicas, Faculdade de Ciências e Letras, Universidade Estadual Paulista - UNESP, \\ Av. Dom Antônio, 2100, Parque Universitário, CEP 19806-900, Assis, SP, Brasil \\ 'Instituto de Biociências, Letras e Ciências Exatas - IBILCE, Universidade Estadual Paulista - UNESP, \\ R. Cristovão Colombo, 2265, Jardim Nazareth, CEP 15054-000, São José do Rio Preto, SP, Brasil \\ *e-mail: karinafcla@gmail.com
}

Received: October 23, 2018 - Accepted: August 20, 2019 - Distributed: February 28, 2021

(With 3 figures)

\begin{abstract}
Contamination of primary and cell cultures by mycoplasmas is one of the main economic and biological pitfalls in basic research, diagnosis and manufacture of biotechnological products. It is a common issue which may be difficult to conduct surveillance on. Mycoplasma presence may affect several physiological parameters of the cell, besides being considered an important source of inaccurate and/or non-reproducible scientific results. Each cell type presents characteristical symptoms, mainly morphological, that indicate a contamination by mycoplasma. HEp- 2 cells originate from carcinoma of the larynx and are, therefore, part of the respiratory tract, which is one of mycoplasma habitats. Despite the importance these cells in several biological research (evaluation of cell proliferation and migration, apoptosis, antiviral and antitumor compounds), the alterations induced by mycoplasma contamination in HEp-2 cells have not yet been described. Here, we describe the progressive morphological alterations in culture of HEp-2 cells infected with mycoplasma, as well as the-diagnosis of the infection and its treatment. Mycoplasma contamination described within this work led to cytoplasm elongation, cell-to-cell spacing, thin plasma membrane projections, cytoplasmic vacuoles, fusion with neighboring cells, and, finally, cell death. Contamination was detected by fluorescence imaging (DAPI) and $\mathrm{PCR}$ reactions. The cultures were treated with $\mathrm{BM}-\mathrm{Cyclin}$ antibiotic to eliminate contamination. The data presented here will be of relevance to researchers whose investigations involve cell culture, especially respiratory and HEp- 2 cells.
\end{abstract}

Keywords: cell culture, HEp-2 cells, mycoplasma, contamination, treatment.

\section{Diagnóstico e tratamento de células HEp-2 contaminadas por micoplasma}

\section{Resumo}

A contaminação de culturas primárias e celulares por micoplasmas é uma das principais armadilhas econômicas e biológicas da pesquisa básica, diagnóstico e fabricação de produtos biotecnológicos. Trata-se de uma contaminação rotineira, mas de difícil acompanhamento. A presença de micoplasma pode afetar vários parâmetros fisiológicos da célula, além de ser considerada uma importante fonte de resultados científicos imprecisos e/ou não reprodutíveis. Cada tipo de célula apresenta sintomas característicos, principalmente morfológicos, que indicam uma contaminação por micoplasma. As células HEp-2 são originárias do carcinoma da laringe e, portanto, fazem parte do trato respiratório, um dos habitats do micoplasma. Apesar da importância destas células em diversas pesquisas biológicas (avaliação da proliferação e migração celular, apoptose, compostos antivirais e antitumorais), as alterações decorrentes da contaminação por micoplasma nestas células ainda não foi descrita. Aqui, descrevemos as alterações morfológicas progressivas na cultura de células HEp-2 infectadas por micoplasma, bem como o diagnóstico da infecção e seu tratamento. A contaminação por micoplasma descrita neste trabalho resultou em alongamento citoplasmático, espaçamento entre células, projeções delgadas da membrana plasmática, vacúolos citoplasmáticos, fusão de células vizinhas e, finalmente, morte celular. A contaminação foi detectada por imagens de fluorescência (DAPI) e reações de PCR. As culturas foram tratadas com antibiótico BM-Cyclin para eliminar a contaminação. Os dados aqui apresentados serão de relevância para pesquisadores cujas investigações envolvem cultura celular, principalmente células respiratórias e HEp-2.

Palavras-chave: cultura celular, células HEp-2, micoplasma, contaminação, tratamento. 


\section{Introduction}

The employment of cell line culture in biological research has been an important tool for over 100 years, due to some peculiar features of these cells. They can proliferate endlessly and maintain their original tissue-characteristic, as long as some manipulation conditions are present. Therefore, they are widely used as a model for several physiological and pathological studies at both cellular and molecular level.

Irrespective of the technological development in biomedical research, contamination of cell cultures with mycoplasma remains a challenge. The mycoplasmas, firstly isolated in 1956 (Robinson et al., 1956), are the smallest free-living bacteria, with diameters of $300-800 \mathrm{~nm}$. These pleomorphic microorganisms have no cell wall. Owing to their small size and flexibility, they are able to-pass through 220-450 nm filters, which are commonly used in cell cultures. The identification of mycoplasma contamination may be hampered by the fact that this microorganism does not alter the turbidity of culture medium, even though the physiology, morphology and gene expression of the cell is altered to a great extent. There may be several sources of mycoplasma contamination, including the researchers themselves, since the respiratory and urogenital mucosa are the most frequent mycoplasma habitats (Phelan, 2007).

HEp-2 are a lineage of laryngeal carcinoma cells widely used in studies prompt to evaluate cellular proliferation and migration, apoptosis, anti-viral and antitumor compounds (Cao et al., 2013; Godoi et al., 2014; Niu et al., 2015; Xiang et al., 2015; Ying et al., 2015). Because they are respiratory tract cells, HEp-2 may be more susceptible to contamination by mycoplasma. Researchers who identify the early morphological signs of mycoplasma contamination are able to diagnose it and make proper decisions about the disposal or treatment of these cells.

In this paper, we describe the progressive morphological alterations presented by HEp-2 cells contaminated with mycoplasma. We present methods for the detection and elimination of mycoplasma from these cells.

\section{Material and Methods}

\subsection{Cell culture}

HEp-2 cells (oropharyngeal carcinoma) were purchased from the Banco de Células do Rio de Janeiro (BCRJ cod. 0101). They were cultured in $25 \mathrm{~cm}^{2}$ cell culture bottles (Corning, NY, USA) in an incubator at $37^{\circ} \mathrm{C}$ and $5 \% \mathrm{CO}_{2}$ in F12 DMEM culture medium (Sigma, St. Louis, MO, USA) supplemented with $5 \%$ inactivated fetal bovine serum (Cultilab, Campinas, SP, Brazil) plus antibiotics and antimycotics $(10,000 \mathrm{units} / \mathrm{mL}$ of penicilin, $10,000 \mu \mathrm{g} / \mathrm{mL}$ of streptomycin and $25 \mu \mathrm{g} / \mathrm{mL}$ of amphotericin B) (Life Technologies, Gaithersburg, MD, USA).

\subsection{Cell subculture}

The bottles were maintained under the culture conditions until reaching $80-100 \%$ confluency. All material used was sterile and disposable. For the subculture, the culture medium was removed with the aid of serological pipettes and the cell monolayer was washed twice gently with $0.15 \mathrm{M} \mathrm{NaCl} . \mathrm{NaCl}$ was replaced by Tryple $(0.5 \mathrm{~mL})$ (Life Technologies) and held for $5 \mathrm{~min}$ at $37^{\circ} \mathrm{C}$. Seventy percent of detached cells were discarded and $30 \%$ were kept in culture under the same conditions described in the item above.

\subsection{Detection of mycoplasma by fluorescence microscopy}

HEp-2 cells $\left(5 \times 10^{4}\right)$ collected after subculture were added on poly-1-lysine (Sigma) treated coverslips, subjected to successive washes with ice-cold sodium phosphate-buffered saline (PBS; Sigma) and mounted on slides using ProLong Gold plus DAPI as recommended by the manufacturer (Invitrogen, Carlsbad, CA, USA). The image capture was performed using a Nikon Eclipse Ti fluorescence inverted microscope coupled in a Nikon Sight digital camera. The images were analyzed in NIS-Elements Software (Sousa-Rocha et al., 2015).

\subsection{Detection of mycoplasma by PCR}

Genomic DNA from HEp-2 cells was extracted and purified via precipitation with $\mathrm{NaCl}$ and ethanol (Stocco et al., 2012), from $1 \times 10^{6}$ cells. For the execution of the PCR the primers GPO3 (5'GGG AGC AAA CAG GAT TAG ATA CCC T3') and MGSO (TGC ACC ATC TGT CAC TCT GTT AAC CTC3') were used that amplify a part of the $16 \mathrm{~S}$ unit gene of any species of the genus mycoplasma (Van Kuppeveld et al., 1992). For the PCR reaction, $1 \mu \mathrm{L}$ of the DNA of the extracted samples was used, $200 \mu \mathrm{M}$ of each triphosphate deoxynucleotide (dTTP, dATP, dCTP, dGTP), 10 pmol of each primer in solution containing $10 \mathrm{mM}$ Tris- $\mathrm{HCl} \mathrm{pH} 8.0, \mathrm{KCl} 50 \mathrm{mM}$ and $1.5 \mathrm{mM} \mathrm{MgCl} 2$ to a final volume of $10 \mu \mathrm{L}$. Reaction conditions were: initial denaturation at $94{ }^{\circ} \mathrm{C}$ for $5 \mathrm{~min}$, 30 cycles at $94{ }^{\circ} \mathrm{C}$ for $60 \mathrm{sec}$, primer annealing at $55^{\circ} \mathrm{C}$ for $60 \mathrm{sec}$ and extension at $72{ }^{\circ} \mathrm{C}$ for $120 \mathrm{sec}$, and the last step at $72{ }^{\circ} \mathrm{C}$ for $120 \mathrm{sec}$ for final extension (Van Kuppeveld et al., 1992). The amplified products were applied in 1\% agarose gel, submitted to electrophoresis and stained with GelRed (Biotium) for visualization in transilluminator.

\subsection{Anti-mycoplasma treatment}

Cells identified as contaminated with mycoplasma were treated with BM-Cyclin (Tiamulin-hydrogenfumarat and Minocyclinhydrochloride) according to the manufacturer's instructions (Roche, Mannheim, Germany). The culture medium was aspirated off and replaced with a new one containing BM-Cyclin $1(10 \mu \mathrm{g} / \mathrm{mL})$. After 3 days of culture, culture medium plus BM-Cyclin $2(5 \mu \mathrm{g} / \mathrm{mL})$ was replaced. The antibiotic remained in the culture for 4 days. This cycle was repeated 3 times and the contamination by mycoplasma checked at the end of each cycle. 


\section{Results}

\subsection{Surveillance of morphological changes in cell culture}

HEp-2 cells are adherent cells and slightly elongated. Cells in division were easily observed. Vacuoles, cell debris and nonadherent cells were rarely detected (see Figure 1A). After contamination by mycoplasma, cells progressively presented morphological alterations (see Figure 1B-F). Initially, they became more elongated and distant from each other. Plasma membrane extensions markedly appeared, which resembled spicules (see
Figure 1B). These alterations became more pronounced over the course of a few days and the cell culture presented cytoplasmic vacuoles, multinucleated masses and a reduction in the number of adherent cells (see Figure 1C-E). Finally, the few adherent cells exhibited fusiform morphology, extensive spicules and absence of cell proliferation (see Figure 1F). It is also important to mention that the symptoms of infection within each new subculture appeared more intensively. In addition to the morphological modifications, the cells showed a decline in their growth rate and the culture medium presented rapid acidification.
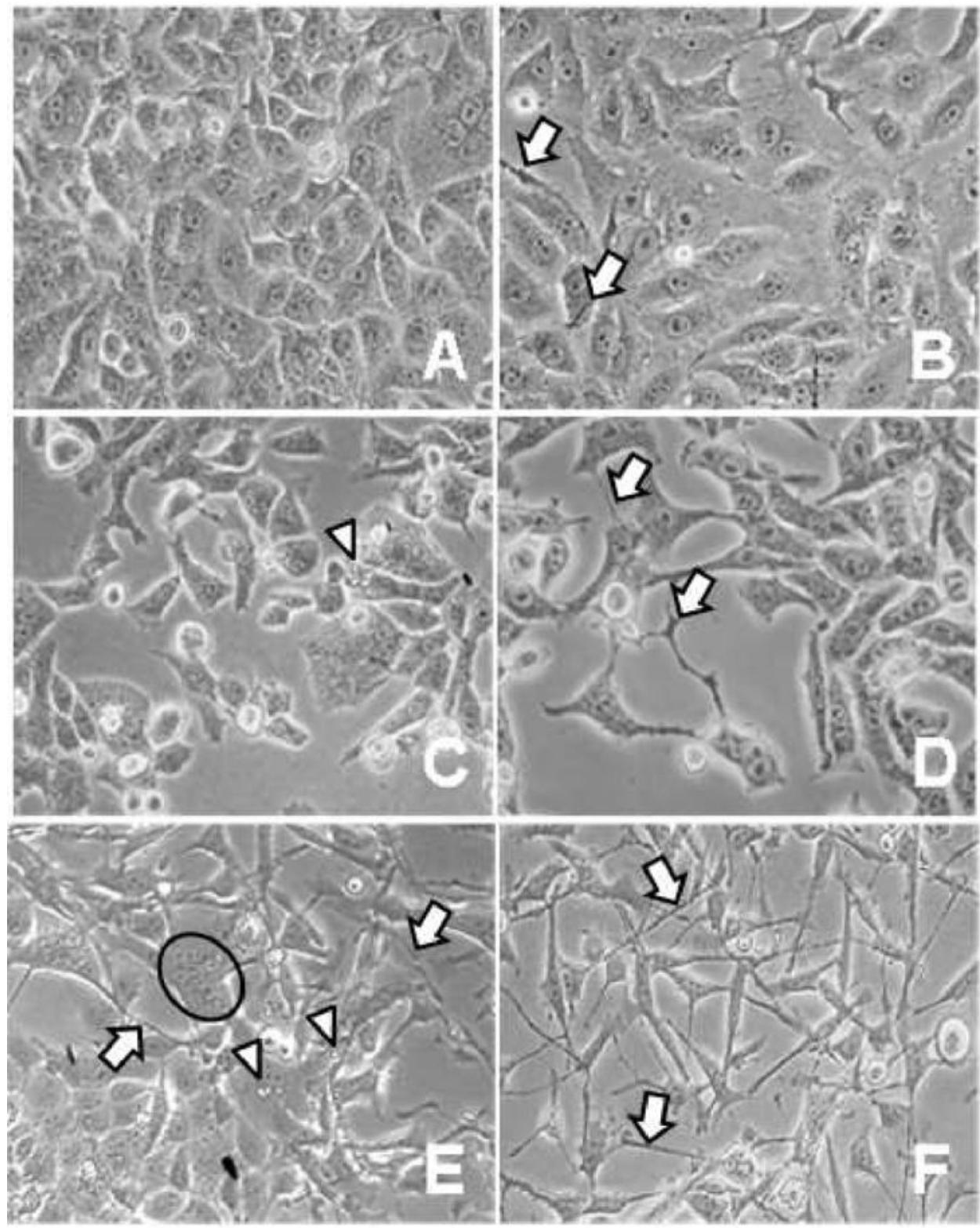

Figure 1. Morphological changes in HEp-2 cells contaminated with mycoplasma. Cells were observed under a white light optic microscope (objective 40x). (A) uncontaminated cells; (B-F) Evolution of morphological changes in contaminated cells, showing elongated spicules (arrows), vacuoles (arrowhead) and multinucleated mass (region marked by a circle). 


\subsection{Diagnosis of mycoplasma contamination}

HEp-2 cells were submitted to the diagnosis of mycoplasma infection using two different methodologies: fluorescence and PCR (see Figure 2). The samples subjected to fluorescence were observed through the fluorochrome DAPI. In these samples, both the cell nucleus and the membrane showed fluorescence (see Figure 2A, B). The nucleus fluorescence was more intense, but the membrane marking was also easily observed, suggesting the presence of mycoplasma in the samples. The PCR reaction, using primers specific for mycoplasma, confirmed our suspicions. Amplification of the specific 270bp gene fragment was negative for the cell culture samples in which no morphological change was observed (see Figure 2C). In samples suspected of contamination, there was amplification of a band of $270 \mathrm{bp}$ corresponding to the presence of genetic material of mycoplasma.

\subsection{Treatment for elimination of mycoplasma contamination}

Treatment of HEp-2 cells with BM-Cyclin antibiotic started at the first signs of morphological alteration in cell culture (see Figure 1B). According to the manufacturer's recommendations, the cultures were initially treated with the compound BM-Cyclin 1 and, in the sequence, with the compound BM-Cyclin 2, thus, closing the cycle. There were progressive improvements during the cell treatment cells with BM-Cyclin-1. BM-Cyclin 2 reduced the growth rate and the morphological enhancements of the cells. At the end of each cycle, a new PCR test was performed. Amplification of the $270 \mathrm{bp}$ gene was negative in the third cycle (see Figure 3A). At that time, cells were also submitted to fluorescence for observation of genetic material in their nucleus (see Figure 3B, C). Fluorescence images showed only the nuclei of the cells stained, without any indication of genetic material in the cell membrane of the samples. This result was interpreted as negative for mycoplasma.

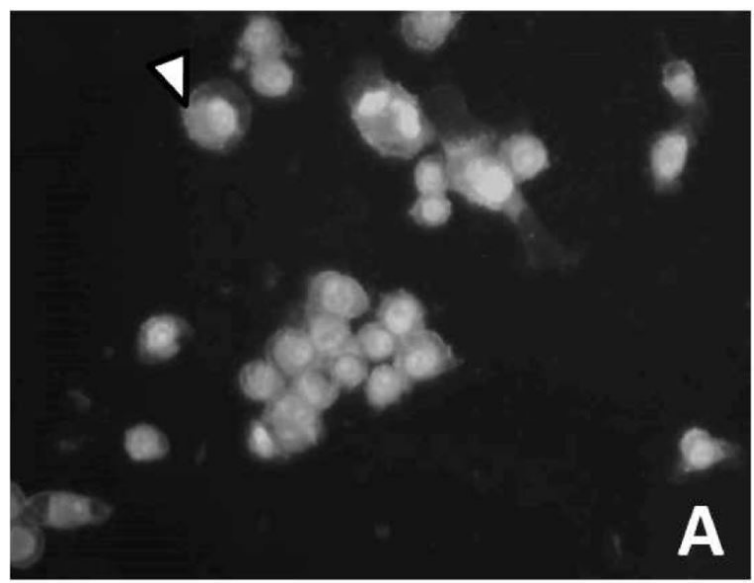

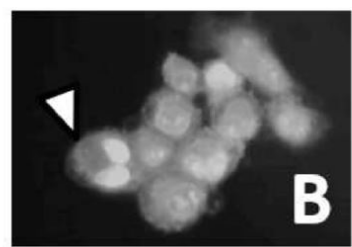

mycoplasma

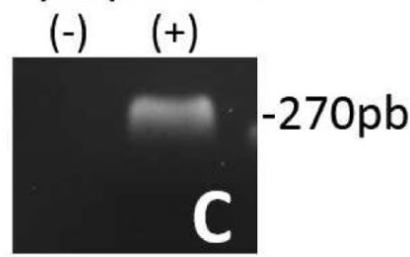

Figure 2. Detection of mycoplasma contamination in HEp-2 cells. Cell samples were subjected to fluorescent labeling with DAPI (A, B; objective 40x) and PCR (C) in the presence of specific primers [(-) uncontaminated samples and (+) contaminated samples]. Strong fluorescent labeling is observed in the membrane of cells (arrowhead).
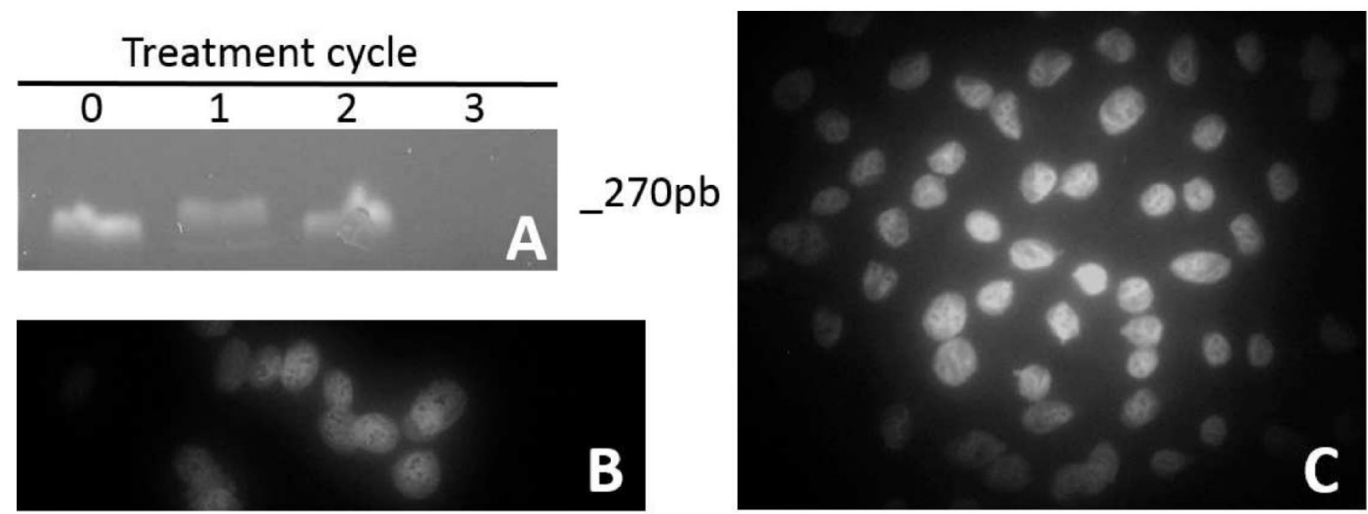

Figure 3. Elimination of mycoplasma contamination in HEp-2 cells. Cells were submitted to 3 cycles of BM-Cyclin treatment and evaluated by PCR at the end of each cycle (A). At the end of the treatment, the cells were subjected to fluorescent labeling with DAPI (B, C; objective 40x). 


\section{Discussion}

The contamination of cell cultures by mycoplasma is recognized as one of the most serious and persistent problems in cell culture, what culminates in a large source of false and non-reproducible scientific results (Armstrong et al., 2010; Laborde et al., 2010; Volokhov et al., 2011). Different cells may present diverse morphological and physiological signals when infected by mycoplasma (Nübling et al., 2015). HEp-2 cells are used in a wide range of biological assays and may be contaminated by mycoplasma. The knowledge about the morphological alterations in HEp-2 cells contaminated by mycoplasma may help researchers at the surveillance and maintenance of their cell cultures.

Mycoplasmas are bacteria distributed in about 20 species. Most of mycoplasma are extracellular parasites, with ability to adhere firmly to the membrane of the host cell. That-may cause changes in cell physiology and viability, growth rate, metabolism and gene expression (Nübling et al., 2015). The sources of contamination by mycoplasma are diverse: cross contamination from another cell culture, laboratory equipment, contaminated reagents, fetal bovine serum, cryogenic flasks, culture medium and experimental animals (Corral-Vázquez et al., 2017). The researchers themselves may be a source of mycoplasma contamination since the usual habitat of these microorganisms are the oral, ocular, respiratory, urogenital and digestive tract surfaces. Mycoplasmas are part of the normal microbiota of the respiratory and genital tracts of most people. HEp-2 cells have their origin in the tissues of the respiratory tract (larynx), what may predispose their contamination towards mycoplasma species. According to the FDA about $15 \%$ of all cultures are contaminated with some type of mycoplasma in the United States (Razin, 2012). Studies also show high rates of contamination in laboratories in Europe (25-37\%), Japan (80\%), Argentina (65\%) and Mexico (88.7\%) as reviewed (Corral-Vázquez et al., 2017). The discrepancy in the numbers presented may reflect the frequency with which surveillance and diagnosis for mycoplasma are performed at these different locations.

Some mycoplasma species are most commonly found in cell cultures. Mycoplasma arginini and Acholeplasma laidlawii are bovine species, M.orale and M.fermentans are human ones, while M.hyorhinis is a porcine one (Barile and Rottem, 1993). They easily spread from one culture to another. The impact of mycoplasma contamination on cultures depend on the specie, the intensity of bacterial replication as well as the infected cell type (Nübling et al., 2015). Generally, there is a decline in the nutritional quality perceived of the culture medium (depletion of sugars, amino acids and fatty acids and cholesterols) (Masukagami et al., 2017). Some mycoplasmas may cause severe cytopathic effect, which can be characterized by slow growth, atrophied, rounded or degenerated cells (Netto et al., 2015; Hegde et al., 2016). Genomic analyzes have revealed that they possess a strict biosynthetic capacity which benefits them in the competition for macromolecules available in the culture medium (Poveda, 1998). That hinders the cell and leads to physiological collapse, loss of membrane integrity and other essential cellular functions. Non-fermenting mycoplasma species utilize the arginine dehydrolase to generate ATP. Therefore, they rapidly deplete the arginine pool for the host cell, which affects protein synthesis and, consequently, cell growth and multiplication (Schimke, 1967). The process of mycoplasma adhesion allows the release of enzymes (metabolites) directly into the cell membrane as reviewed (Persaud, 1999). HEp-2 cells contaminated by mycoplasma show morphological modifications which illustrate the damage caused in this cell culture. Progressively, the cells exhibited cytoplasmic elongation, cell-to-cell spacing, thin projections of the plasma membrane, cytoplasmic vacuoles, fusion with neighboring cells, and, finally, cell death.

Several physiologic studies are performed using HEp-2 cells (Cao et al., 2013; Godoi et al., 2014; Niu et al., 2015; Xiang et al., 2015; Ying et al., 2015). In all biological events, there are reports of interference in the results due to the presence of mycoplasma contamination.

Mycoplasmas may alter the course of viral infection (Kubo et al., 2006), as well as interfere with the antitumor (Vande Voorde et al., 2014) and antiviral drugs (Singer et al., 1972), and also have impact on proliferation, migration, and apoptosis process (Suleman et al., 2016; Shi et al., 2017). Their presence in cultures is one of the major sources of inaccurate scientific results, what may lead to difficulties in reproducing published data, as well as loss of cell stocks and loss of reagents. They cause, therefore scientific and economic losses to the laboratories, colleges and society who could benefit from technological advances described by reproducible works.

A strict control regarding mycoplasma presence is recommended nowadays in the following situations: (i) cells deposited, amplified and commercialized in cell banks; (ii) extracted products, concentrates and cell derivatives; and; (iii) all health-related products that have direct or non- direct contact with cell cultures at some stage of their production. Among the methods for mycoplasma detection, there are culture in solid or liquid medium, fluorescence of genetic material, quantification of enzymatic activity and polymerase chain reaction (PCR) (Masters and Stacey, 2007).

The culture in solid or liquid medium allows the growth of aerobic, microaerobic and anaerobic mycoplasmas, however, it is a method that requires 30 days to obtain the results. The enzyme activity detection measures the activity of the enzyme arginine deiminase trymidine. The method is based on arbitrary units and is not very sensitive the early stages of infection. The detection of mycoplasma by fluorescence is premised on the marking of the microorganism genetic material on the cell surface. The most commonly used fluorochemicals in these analyzes are Hoechst 33342 and DAPI, which are two DNA intercalators (Chen, 1977). Fluorescence is observed in the cell nucleus and in the plasma membrane when contamination is positive. The method is not expensive, 
besides being quick (approximately 1-2 days) and easy to interpret. In the same vein, the use of PCR technique for the detection of mycoplasma has expanded rapidly because of its efficiency time-saving (1-2 days) and sensitivity attributes. The genus-specific primers used are complementary to the conserved $16 \mathrm{~S}$ (rRNA) sequence common to the genera Mycoplasma, Acholeplasma, Ureaplasma and Spiroplasma. The primers used in this study were the GPO3 and MGSO primers, complementary to the V2 and V7 regions, and are in positions 798-3 'and 1055-3' of the DNA (Van Kuppeveld et al., 1992). The PCR product is a $270 \mathrm{pb}$ fragment, easily visualized on a $1 \%$ agarose gel. From our results, HEp-2 cells that showed morphological alterations compatible with mycoplasma contamination were submitted to fluorescence and PCR reactions. The fluorescence images evidenced cell nucleus and diffuse labeling on the cell membrane, which indicated a positive result for mycoplasma contamination. The PCR reaction of these samples was also positive.

The most reliable strategy of eliminating mycoplasma contamination is the disposal of the contaminated culture as well as the material/reagent used on it. Since the first descriptions of mycoplasma contaminations, several methods have been developed,-including the use of antibiotics like tetracycline, kanamicin, novobioncin (Uphoff et al., 1992). When culture disposal is not an alternative, concomitant administration of some antibiotics drastically reduces contamination. In this work, we chose to treat the cells with BM-Cyclin reagent which is a combination of two antibiotics, namely pleuromutilin and tetracycline derivatives. BM-Cyclin treatment proved to be efficient in our HEp-2 cell cultures after 3 cycles of treatment. It helped at recovering morphological characteristics of healthy cells and, as a result, there was no mycoplasma detection on the fluorescence and PCR assays after the proposed cycle of treatment. As for the literature, the administration of BM-Cyclin to different cells shown to be effective, with low index of resistance and toxicity (Molla Kazemiha et al., 2009; Mariotti et al., 2012; Uphoff et al., 2012).

\section{Conclusion}

HEp-2 cells contaminated with mycoplasma showed several morphological alterations-cytoplasm elongation, cell-to-cell spacing, thin plasma membrane projections, cytoplasmic vacuoles, fusion with neighboring cells, and cell death. The contamination was confirmed through the use of fluorescence imaging (DAPI) and PCR reactions. Moreover, it was eliminated by administration of Bm-Cyclin antibiotic 3-cycles treatment. The cellular aspects described here are of relevance during the surveillance of cell cultures, in order to avoid economic and biological losses in basic and applied research.

\section{Acknowledgements}

This work was supported by Fundação de Amparo à Pesquisa do Estado de São Paulo (FAPESP - Grant 2014/22637-3). We acknowledge Dr Marcelo Fábio Gouveia Nogueira for granting us permission to use the fluorescence microscope.

\section{References}

ARMSTRONG, S.E., MARIANO, J.A. and LUNDIN, D.J., 2010. The scope of mycoplasma contamination within the biopharmaceutical industry. Biologicals, vol. 38, no. 2, pp. 211-213. http://dx.doi. org/10.1016/j.biologicals.2010.03.002. PMid:20362237.

BARILE, M.F. and ROTTEM, S., 1993. Mycoplasmas in cell culture. In: I. KAHANE and A. ADONI, eds. Rapid diagnosis of mycoplasmas. Switzerland: Springer, vol. 62, pp. 155-193. http:// dx.doi.org/10.1007/978-1-4615-2478-6 12 .

CAO, X., LIU, R., LIU, J., HUO, Y., YANG, W., ZENG, M. and YANG, C., 2013. A novel polysaccharide from lentinus edodes mycelia exhibits potential antitumor activity on laryngeal squamous cancer cell line HEp-2. Applied Biochemistry and Biotechnology, vol. 171, no. 6, pp. 1444-1453. http://dx.doi.org/10.1007/s12010013-0441-6. PMid:23955351.

CHEN, T.R., 1977. In situ detection of mycoplasma contamination in cell cultures by fluorescent Hoechst 33258 stain. Experimental Cell Research, vol. 104, no. 2, pp. 255-262. http://dx.doi. org/10.1016/0014-4827(77)90089-1. PMid:65285.

CORRAL-VÁZQUEZ, C., AGUILAR-QUESADA, R., CATALINA, P., LUCENA-AGUILAR, G., LIGERO, G., MIRANDA, B. and CARRILLO-ÁVILA, J.A., 2017. Cell lines authentication and mycoplasma detection as minimun quality control of cell lines in biobanking. Cell and Tissue Banking, vol. 18, no. 2, pp. 271-280. http://dx.doi.org/10.1007/s10561-017-9617-6. PMid:28255773.

GODOI, A.M., FACCIN-GALHARDI, L.C., LOPES, N., RECHENCHOSKI, D.Z., DE ALMEIDA, R.R., RICARDO, N.M., NOZAWA, C. and LINHARES, R.E., 2014. Antiviral activity of sulfated polysaccharide of Adenanthera pavonina against poliovirus in HEp-2 cells. Evidence-Based Complementary and Alternative Medicine, vol. 2014, pp. 712634. http://dx.doi. org/10.1155/2014/712634. PMid:25221609.

HEGDE, S., HEGDE, S.M., ROSENGARTEN, R. and CHOPRADEWASTHALY, R., 2016. Mycoplasma agalactiae induces cytopathic effects in infected cells cultured in vitro. PLoS One, vol. 11, no. 9, pp. e0163603. http://dx.doi.org/10.1371/journal. pone. 0163603 . PMid:27662492.

KUBO, M., NISHITSUJI, H., KURIHARA, K., HAYASHI, T., MASUDA, T. and KANNAGI, M., 2006. Suppression of human immunodeficiency virus type 1 replication by arginine deiminase of Mycoplasma arginini. The Journal of General Virology, vol. 87, no. 6, pp. 1589-11593. http://dx.doi.org/10.1099/vir.0.815490. PMid:16690923.

LABORDE, S., DEGRAVE, A., LEHMANN, D., JOUETTE, S., ROFEL, C., MULLER, T., HERTZOG, N., ROOK, M. and RIBAULT, S., 2010. Detection of Mollicutes in bioreactor samples by real-time transcription-mediated amplification. Letters in Applied Microbiology, vol. 50, no. 6, pp. 633-638. http://dx.doi. org/10.1111/j.1472-765X.2010.02846.x. PMid:20438617.

MARIOTTI, E., D'Alessio, F., MIRABELLI, P., DI NOTO, R., FORTUNATO, G. and DEL VECCHIO, L., 2012. Mollicutes contamination: a new strategy for an effective rescue of cancer cell lines. Biologicals, vol. 40, no. 1, pp. 88-91. http://dx.doi. org/10.1016/j.biologicals.2011.10.006. PMid:22078664.

MASTERS, J.R. and STACEY, G.N., 2007. Changing medium and passaging cell lines. Nature Protocols, vol. 2, no. 9, pp. 22762284. http://dx.doi.org/10.1038/nprot.2007.319. PMid:17853884.

MASUKAGAMI, Y., SOUZA, D.P., DAYALAN, S., BOWEN, C., O'Callaghan, S., KOUREMENOS, K., NIJAGAL, B., TULL, D., 
TIVENDALE, K.A., MARKHAM, P.F., MCCONVILLE, M.J., BROWNING, G.F. and SANSOM, F.M., 2017. Comparative metabolomics of Mycoplasma bovis and Mycoplasma gallisepticum reveals fundamental differences in active metabolic pathways and suggests novel gene annotations. mSystems, vol. 2, no. 5, pp. e00055-e17. http://dx.doi.org/10.1128/mSystems.00055-17. PMid:29034329.

MOLLA KAZEMIHA, V., SHOKRGOZAR, M.A., ARABESTANI, M.R., MOGHADAM, M.S., AZARI, S., MALEKI, S. and SHOKRI, F., 2009. PCR-based detection and eradication of mycoplasmal infections from various mammalian cell lines: a local experience. Cytotechnology, vol. 61, no. 3, pp. 117-124. http://dx.doi.org/10.1007/s10616-010-9252-6. PMid:20135349.

NETTO, C., SOCCOL, V.T., SEPULVEDA, L.M. and TIMENETSKY, J., 2015. Experimental infection of BHK21 and vero cell lines with different Mycoplasma spp. Brazilian Journal of Microbiology, vol. 45, no. 4, pp. 1513-1519. http://dx.doi.org/10.1590/S151783822014000400048. PMid:25763061.

NIU, J., HUANG, Y. and ZHANG, L., 2015. CXCR4 silencing inhibits invasion and migration of human laryngeal cancer HEp-2 cells. International Journal of Clinical and Experimental Pathology, vol. 8, no. 6, pp. 6255-6261. PMid:26261502.

NÜBLING, C.M., BAYLIS, S.A., HANSCHMANN, K.M., MONTAG-LESSING, T., CHUDY, M., KRE $\beta$, J., ULRYCH, U., CZURDA, S. and ROSENGARTEN, R., 2015. World Health Organization international standard to harmonize assays for detection of mycoplasma DNA. Applied and Environmental Microbiology, vol. 81, no. 17, pp. 5694-5702. http://dx.doi. org/10.1128/AEM.01150-15. PMid:26070671.

PERSAUD, S.J., 1999. Cell and tissue culture: laboratory procedures in biotechnology. A. Doyle and J. B. Griffiths (Eds), John Wiley \& Sons Ltd, 332 pp, ISBN 0471 98255-5, £55.00, (1999). Cell Biochemistry and Function, vol. 17, no. 4, pp. 289. http://dx.doi.org/10.1002/(SICI)1099-0844(199912)17:4<289::AID$\mathrm{CBF} 845>3.0 . \mathrm{CO} ; 2-\mathrm{B}$.

PHELAN, M.C., 2007. Techniques in mammalian cell tissue culture. Current Protocols in Cell Biology, vol. 36, no. 1, pp. A-3B. http:// dx.doi.org/10.1002/0471143030.cb0101s36. PMid:18228494.

POVEDA, J.B., 1998. Biochemical characteristics in mycoplasma identification. In: R. MILES and R. NICHOLAS, eds. Mycoplasma protocols: methods in molecular biology. Switzerland: Springer Nature, vol. 104, pp. 69-78.

RAZIN, S., 2012. Methods in mycoplasmology: mycoplasma characterization. Amsterdam: Elsevier, vol. 1.

ROBINSON, L.B., WICHELHAUSEN, R.H. and ROIZMAN, B., 1956. Contamination of human cell cultures by pleuropneumonialike organisms. Science, vol. 124, no. 3232, pp. 1147-1148. http:// dx.doi.org/10.1126/science.124.3232.1147. PMid:13380429.

SCHIMKE, R.T., 1967. Studies on the metabolism of arginine by mycoplasma. Annals of the New York Academy of Sciences, vol. 143, no. 1, pp. 573-577. http://dx.doi.org/10.1111/j.1749-6632.1967. tb27703.x. PMid:5233788.

SHI, S., LIU, X. and LI, H., 2017. Downregulation of caspase-3 alleviates mycoplasma pneumoniae-induced apoptosis in alveolar epithelial cells. Molecular Medicine Reports, vol. 16, no. 6, pp. 9601-9606. http://dx.doi.org/10.3892/mmr.2017.7782. PMid:29039549.

SINGER, S.H., FORD, M. and BARON, S., 1972. The influence of mycoplasma infection on the induction of the antiviral state by polyinosinic: polycytidilic acid. Proceedings of the Society for Experimental Biology and Medicine, vol. 139, no. 4, pp. 1413-1416. http://dx.doi.org/10.3181/00379727-139-36374. PMid:4336831.

SOUSA-ROCHA, D., THOMAZ-TOBIAS, M., DINIZ, L.F.A., SOUZA, P.S.S., PINGE-FILHO, P. and TOLEDO, K.A., 2015. Trypanosoma cruzi and its soluble antigens induce NET release by stimulating toll-like receptors. PLoS One, vol. 10, no. 10, pp. e0139569. http://dx.doi.org/10.1371/journal.pone.0139569. PMid:26431537.

STOCCO, B., TOLEDO, K., SALVADOR, M., PAULO, M., KOYAMA, N. and TORQUETI TOLOI, M.R., 2012. Dose-dependent effect of Resveratrol on bladder cancer cells: chemoprevention and oxidative stress. Maturitas, vol. 72, no. 1, pp. 72-78. http:// dx.doi.org/10.1016/j.maturitas.2012.02.004. PMid:22386766.

SULEMAN, M., PRYSLIAK, T., CLARKE, K., BURRAGE, P., WINDEYER, C. and PEREZ-CASAL, J., 2016. Mycoplasma bovis isolates recovered from cattle and bison (Bison bison) show differential in vitro effects on PBMC proliferation, alveolar macrophage apoptosis and invasion of epithelial and immune cells. Veterinary Microbiology, vol. 186, pp. 28-36. http://dx.doi. org/10.1016/j.vetmic.2016.02.016. PMid:27016754.

UPHOFF, C.C., BRAUER, S., GRUNICKE, D., GIGNAC, S.M., MACLEOD, R.A.F., QUENTMEIER, H., STEUBE, K., TÜMMLER, M., VOGES, M., WAGNER, B. and DREXLER, H.G., 1992. Sensitivity and specificity of five different mycoplasma detection assays. Leukemia, vol. 6, no. 4, pp. 335-341. PMid:1375305.

UPHOFF, C.C., DENKMANN, S.A. and DREXLER, H.G., 2012. Treatment of mycoplasma contamination in cell cultures with plasmocin. Journal of Biomedicine \& Biotechnology, vol. 2012, pp. 1-8. http://dx.doi.org/10.1155/2012/267678. PMid:23091342.

VAN KUPPEVELD, F.J., VAN DER LOGT, J.T., ANGULO, A.F., VAN ZOEST, M.J., QUINT, W.G., NIESTERS, H.G., GALAMA, J.M. and MELCHERS, W.J., 1992. Genus- and species-specific identification of mycoplasmas by $16 \mathrm{~S}$ rRNA amplification. Applied and Environmental Microbiology, vol. 58, no. 8, pp. 2606-2615. http://dx.doi.org/10.1128/AEM.58.8.26062615.1992. PMid:1381174.

VANDE VOORDE, J., SABUNCUOĞLU, S., NOPPEN, S., HOFER, A., RANJBARIAN, F., FIEUWS, S., BALZARINI, J. and LIEKENS, S., 2014. Nucleoside-catabolizing enzymes in mycoplasma-infected tumor cell cultures compromise the cytostatic activity of the anticancer drug gemcitabine. The Journal of Biological Chemistry, vol. 289, no. 19, pp. 13054-13065. http:// dx.doi.org/10.1074/jbc.M114.558924. PMid:24668817.

VOLOKHOV, D.V., GRAHAM, L.J., BRORSON, K.A. and CHIZHIKOV, V.E., 2011. Mycoplasma testing of cell substrates and biologics: review of alternative non-microbiological techniques. Molecular and Cellular Probes, vol. 25, no. 2-3, pp. 69-77. http:// dx.doi.org/10.1016/j.mcp.2011.01.002. PMid:21232597.

XIANG, C., LV, Y., WEI, Y., WEI, J., MIAO, S., MAO, X., GU, X., SONG, K. and JIA, S., 2015. Effect of EphA7 silencing on proliferation, invasion and apoptosis in human laryngeal cancer cell lines HEp-2 and AMC-HN-8. Cellular Physiology and Biochemistry, vol. 36, no. 2, pp. 435-445. http://dx.doi. org/10.1159/000430110. PMid:25968442.

YING, X.J., JIN, B., CHEN, X.W., XIE, J., XU, H.M. and DONG, P., 2015. Oxymatrine downregulates HPV16E7 expression and inhibits cell proliferation in laryngeal squamous cell carcinoma HEp-2 cells in vitro. BioMed Research International, vol. 2015, pp. 150390. http://dx.doi.org/10.1155/2015/137482. PMid:25811021. 